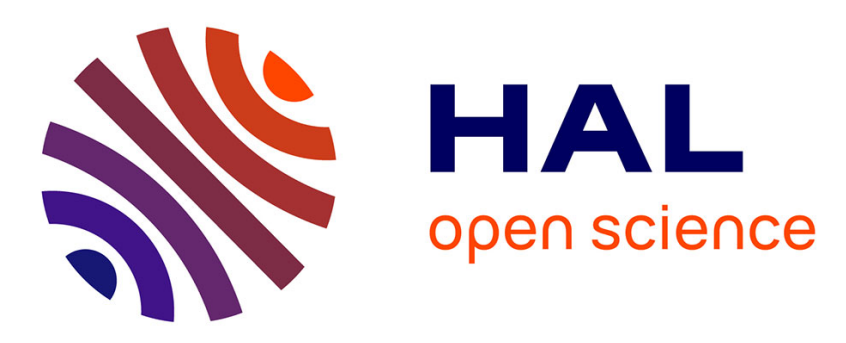

\title{
An approach to model shaft voltage of wound rotor synchronous machines
}

\author{
K. Darques, A. Tounzi, Y. Le Menach, K. Beddek, M. Biet-Evrard
}

\section{To cite this version:}

K. Darques, A. Tounzi, Y. Le Menach, K. Beddek, M. Biet-Evrard. An approach to model shaft voltage of wound rotor synchronous machines. The 17th Biennial Conference on Electromagnetic Field Computation(CEFC 2016), Nov 2016, Miami, United States. 10.1109/CEFC.2016.7816291. hal-01973668

\section{HAL Id: hal-01973668 \\ https://hal.science/hal-01973668}

Submitted on 8 Jan 2019

HAL is a multi-disciplinary open access archive for the deposit and dissemination of scientific research documents, whether they are published or not. The documents may come from teaching and research institutions in France or abroad, or from public or private research centers.
L'archive ouverte pluridisciplinaire HAL, est destinée au dépôt et à la diffusion de documents scientifiques de niveau recherche, publiés ou non, émanant des établissements d'enseignement et de recherche français ou étrangers, des laboratoires publics ou privés. 


\title{
An approach to model shaft voltage of wound rotor synchronous machines
}

\author{
K. Darques ${ }^{1,2}$, A. Tounzi ${ }^{1}$, Y. Le Menach ${ }^{1}$, K. Beddek ${ }^{2}$ and M. Biet-Evrard ${ }^{2}$ \\ ${ }^{1}$ Univ. Lille, Centrale Lille, Arts et Métiers ParisTech, HEI, EA 2697 - L2EP - Laboratoire \\ d'Electrotechnique et d'Electronique de Puissance, F-59000 Lille, France \\ ${ }^{2}$ EDF R\&D/THEMIS, 7 boulevard Gaspard Monge, F-91120 Palaiseau, France
}

\begin{abstract}
In the case of high power synchronous machines, shaft voltage can induce high currents yielding to bearing damages but it can also constitutes a variable to be used to diagnosis some machine defects. Therefore, it is important to well model the phenomenon in order to use it in further diagnosis tool.
\end{abstract}

Index Terms-Fault diagnosis, finite element model, shaft voltage, synchronous generator.

\section{INTRODUCTION}

Several causes such as magnetic asymmetries, short-circuits either in the stator or the rotor, etc. can generate a circumferential magnetic flux. The latter induces a shaft voltage which is an electric potential difference between both ends of the shaft (Fig. 1a) leading to possible high bearing currents. However, by differentiating between the various causes, it can be used as a preventive diagnostic variable. In previous works $[1,2]$, this voltage is modeled using FEA through an external circuit coupling the shaft to the casing. To go deeper in the physical representation of the shaft voltage while studying the effect of each cause, we propose an approach considering the whole machine as a magnetic tore.

\section{PROPOSED APPROACH}

In order to model the shaft voltage, a 2-pole simplified synchronous structure is studied at no load using finite element analysis. It is constituted of a shaft, a rotor with 3 slots per pole, a smooth cylindrical stator, a casing and an area relative to the air around the machine. Moreover, a regular prismatic mesh is used to avoid numerical errors. The approach to determine this voltage consists in using a set of equidistant virtual search coils [3] that capture tangential magnetic flux between the center of the machine and the outer casing perimeter at different positions (Fig. 1b). Putting these coils in series is equivalent to a tore winding all around the machine that catches the circumferential magnetic flux.

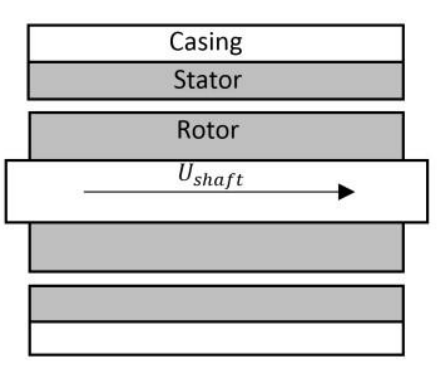

Fig. 1a. Location of the shaft voltage due to a magnetic asymmetry

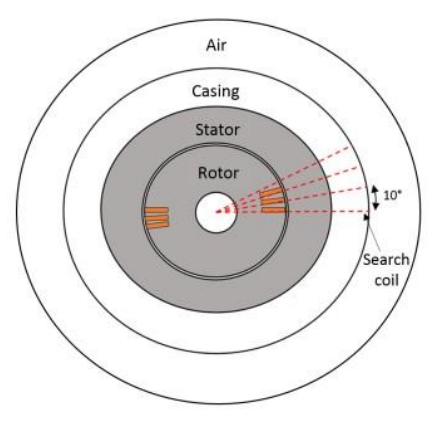

Fig. 1b. Schema describing the positioning of the search coils
Hence, each search coil catches a leakage flux leading to an emf arising at its end. In the case of an ideal healthy machine, the emfs induced in the coils have the same magnitude but are phase shifted by the same angle $2 \pi / \mathrm{n}$ (n being the search coil number). Therefore, the sum of all the fluxes, and all the emfs, is nil while this is not the case if a fault occurs. The analysis of this resultant emf can then be used to diagnosis a possible defect.

\section{APPLICATION TO THE CASE OF STATIC ECCENTRICITY}

To highlight the effectiveness of the proposed approach, a study is carried out on a simplified structure whose geometrical quantities are similar to those of a high power synchronous generator. Using vector potential formulation, both healthy case and a $20.8 \%$ static eccentricity have been studied. Fig. 2 shows the magnetic flux density distribution in a cross section of the machine in the case of static eccentricity and Fig. 3 presents the time shaft voltages. The latter is almost nil in the case of healthy conditions while it shows a sinusoidal behavior at the rated frequency due to the static eccentricity $[1,2]$.

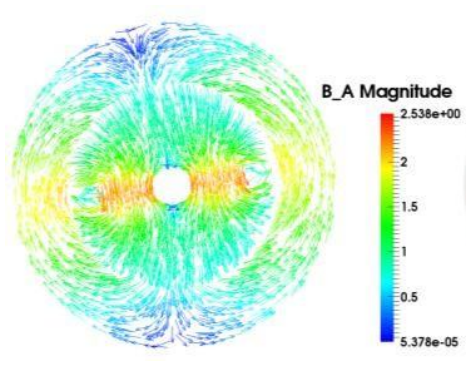

Active part

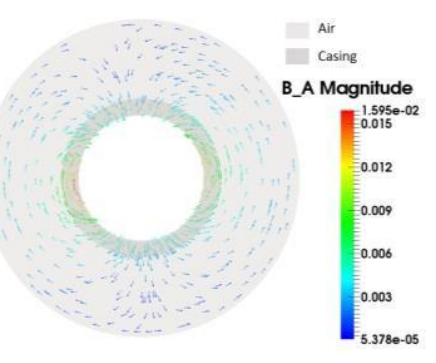

Casing and air
Fig.2. Magnetic flux density in the cross section of the machine with static eccentricity
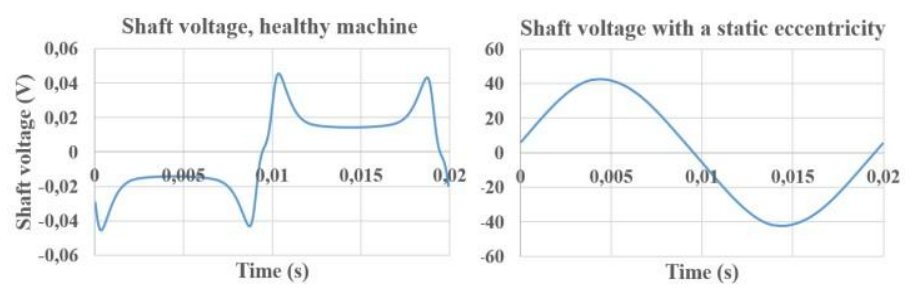

Fig. 3. Shaft voltages

In the extended version, the effect of the static eccentricity severity will be presented along with the results relative to other defects.

\section{REFERENCES}

[1] J-E Torlay, C. Corenwider, A. Audoli, J. Herigault, A. Foggia "Analysis of shaft voltages in large synchronous generators", Electric Machines and Drives, 1999. International Conference IEMD '99, pp 607-609.

[2] D. De Canha, W.A. Cronje, A.S. Meyer, S.J. Hoffe "Methods for diagnosing static eccentricity in a synchronous 2 pole generator" Power Tech, 2007 IEEE Lausanne, pp 2162-2167.

[3] T. Henneron et al «Evaluation of 3D finite element method to study and design a soft magnetic composite machine" IEEE Transaction on Magnetics, Vol. 40, $\mathrm{N}^{\circ} .2$, p. 786-789, 2004. 